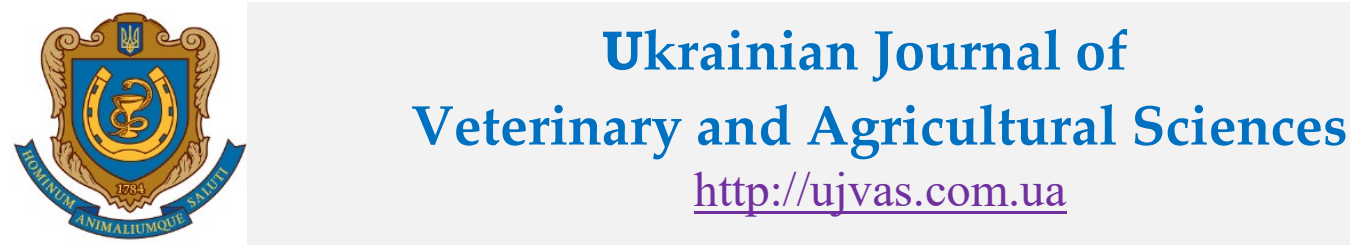

Stepan Gzhytskyi National University of Veterinary Medicine and Biotechnologies Lviv

\begin{tabular}{l|l|l} 
original article & UDC 619:617:619.612:636,2 & doi: 10.32718/ujvas2-3.08
\end{tabular}

Volume 2

Number 3

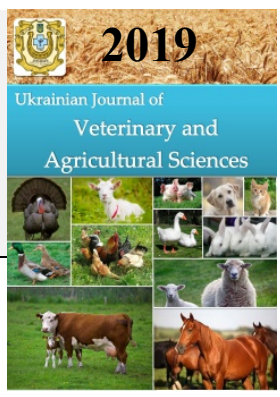

\title{
Structural proteins of plasmolemma of the jejunum absorbing enterocytes of cattle fetus in early fetal period
}

\author{
D. M. Masiuk
}

Dnipro State Agrarian and Economic University, Serhii Efremov Str., 25, Dnipro, 49600, Ukraine

\begin{tabular}{l} 
Article info \\
Received 07.11.2019 \\
Received in revised form \\
09.12 .2019 \\
Accepted 10.12.2019 \\
\hline Correspondence author \\
Dmytro Masiuk \\
Tel.: +38-050-636-62-37 \\
E-mail: dimasiuk@gmail.com \\
\hline
\end{tabular}

2019 Masiuk D. M. This is an openaccess article distributed under the terms of the Creative Commons Attribution License, which permits unrestricted use, distribution, and reproduction in any medium, provided the original author and source are credited.

\section{(cc) $\mathrm{BY}$}

Contents

1. Introduction

2. Materials and methods ....... 33

3. Results and discussion ....... 33

4. Conclusions ................ 37

References ...................... 37

\begin{abstract}
The data on the concentration of structural proteins of plasmolemma of the absorption enterocytes of the cattle fetus in the early fetal period are presented. Changes in the protein composition of the apical and basolateral membranes of enterocytes are manifested, characterized not only by changes in their ratio within different cell domains, but also by the dynamic redistribution of the number of different fractions of polypeptides between the poles of these cells. Analysis of the results of electrophoresis of apical membranes of the cattle fetus enterocytes in the early fetal period indicates a decrease in the content of low molecular weight protein fractions and an increase in high molecular weight. In the apical membranes of enterocytes of two-month-old cattle fetus, 25 protein fractions with a molecular weight of 9.6 to $205 \mathrm{kDa}$ were detected. In the basolateral membranes revealed 23 protein fractions with a molecular weight of 9.6 to $120 \mathrm{kDa}$. High molecular weight fractions of polypeptides with molecular weights of $250 \mathrm{kDa}$ and $300 \mathrm{kDa}$ appear from the age of three months of embryos of calves. In the basolateral membranes of enterocytes, there is a slight decrease in the content of low molecular weight protein fractions, and from the four months of age of cattle fetus, high molecular weight fractions of polypeptides with molecular weights of $22.5 \mathrm{kDa}$ and $155 \mathrm{kDa}$ appear, which are absent in basolateral membranes of enterocytes. Two-monthold fetus lack proteins with a molecular weight of $19 \mathrm{kDa}, 24 \mathrm{kDa}$, and $66 \mathrm{kDa}$ in the apical part, whereas proteins with a mass of $22.5 \mathrm{kDa}, 155 \mathrm{kDa}, 170-185 \mathrm{kDa}$, and $205 \mathrm{kDa}$ are absent on the basolateral membrane. In the apical membrane of enterocytes significantly more proteins with a low molecular weight of 9.6-14.2 kDa (1.56 times; $\mathrm{P} \leq 0.001$ ), whereas in the basolateral membrane a significantly higher concentration of proteins with a molecular weight of $15.5 \mathrm{kDa}(2.06$ times; $\mathrm{P} \leq 0.001)$ and $17 \mathrm{kDa}(3.62$ times; $\mathrm{P} \leq 0.001)$.
\end{abstract}

Key words: polypeptides, jejunum, enterocytes, apical membrane, basolateral membrane, plasma membrane, molecular weight, fetus, cattle, early fetal period, polyacrylamide gel electrophoresis.

\section{Citation:}

Masiuk, D. M. (2019). Structural proteins of plasmolemma of the jejunum absorbing enterocytes of cattle fetus in early fetal period. Ukrainian Journal of Veterinary and Agricultural Sciences, 2(3), 32-38.

\section{Introduction}

At present, the polarity of epithelial cells has shifted to the vanguard of cell biological research. The plasma membrane of the cell epithelium is divided into two main domains. The apical surface contacts the lumen of the organ, and the basolateral surface contacts the adjacent epithelial cells. The apical and basolateral surfaces perform very different functions and therefore have very different protein and lipid compositions. The apical surface is specialized in the exchange of materials with the cavity, while the basolateral surface is specialized for the interaction with other cells and the bloodstream (St Johnston \& Sanson, 2011).

The epithelium provides the relationship between the outside world and the internal environment of the body (Yeaman \& Nelson, 1999). Epithelial cells are different from other cell types in their organization, which provides a number of unique physiological properties. Most importantly, the closed epithelium allows you to regulate the metabo- lism of nutrients and end products of metabolism between internal and external media (Cereijido \& Shoshani, 2004). Polarized epithelial cells have a characteristic apical-basal polarity axis for vector transport of ions and dissolved molecules. During development, mesenchymal cells are transformed into the epithelium by clumping into aggregates that undergo epithelial differentiation (Nelson, 2009).

The apical and basolateral membrane domains have different morphologies due to their functions. The apical membrane domain of enterocytes is characterized by a brush border consisting of microvilli that enlarge the cell surface and improve tissue absorption and exchange properties (Aroeti et al., 1998). On the basis of their functional features, the apical and basolateral domains of membranes are composed of different proteins and lipids (RodriguezBoulan \& Powell, 1992). On the apical plasma membrane of the intestine cells, for example, many hydrolases, while integrins concentrate in the basolateral domain and facilitate the formation of cell contacts. The composition of mem- 
brane lipids is also slightly different, in particular cholesterol and sphingolipids are concentrated mainly on the apical part, whereas phosphatidylcholine is on the basolateral membrane (Simons \& van Meer, 1988). This polarized architecture is stabilized in epithelial cells by a dense complex of compounds that acts as a barrier against protein or lipid diffusion from one membrane domain to another. Differences in the protein and lipid composition of the two membrane domains are provided by highly specific mechanisms (Caplan, 1997). The mechanisms that transport proteins from TGN to the plasma membrane can be divided into several steps: protein segregation or sorting, budding and transport of vesicles arising from TGN, along intracellular pathways, docking and fusion with membrane (Delacour \& Jacob, 2006). The heterogeneity of epithelial cells can be explained by a flexible phenotype, they target proteins to different membrane domains based on cell type, their cell localization and specialization (Muth \& Caplan, 2003; Rodriguez-Boulan \& Musch, 2005).

The functional properties of absorptive enterocytes are due to the polarization of these cells with the formation of macrodomains of plasmolemma - apical (AM) and basolateral (BM) membranes, which, accordingly, requires some difference in the chemical composition of their bilayer. The data obtained hypothetically indicate stimulation with lycopene by the elongase-desaturase system of fatty acids (Buhai \& Tsvilikhovskyi, 2010).

The transport function of polarized epithelial cells requires that membrane proteins be sorted and stored in the desired apical or basolateral membrane domain. The main sorting site for newly synthesized plasma membrane proteins is the Golgi trans complex (TGN) (exocytic pathway) (Nejsum \& Nelson, 2007; Folsch, 2008). Additionally, in the endocytic pathway, protein distribution occurs between TGN domains, the plasma membrane (Gravotta \& Rodriguez-Boulan, 2007) and different membrane domains (the transcytic pathway) (Casanova \& Mostov, 1990) Some vesicle migration between the TGN and the plasma membrane occurs along the microtubules (Lafont \& Simons, 1994; Jaulin \& Kreitzer, 2007). Joining and fusion of vesicles with the correct membrane domain requires specific binding of vesicles (exocysts) and SNARE complexes (Mellman \& Nelson, 2008).

Epithelial cell polarization is not limited to the separation of two domains of plasma membranes, but also involves the orientation of cytosolic organelles and the cytoskeleton. Highly organized actin microfilaments stabilize microvilli in the apical part of epithelial cells (Tilney \& Mooseker, 1973).

The enterocyte membrane undergoes molecular differentiation during fetal development that expresses several basic stage-specific polypeptides (Masiuk et al., 2008; Tsvilikhovskyi \& Yakymchuk, 2014). Immunoblotting revealed that polypeptides with molecular weights of 120 , $100,87,75$, and $\sim 24 \mathrm{kD}$ of the apical membrane of the small intestine epithelium at birth (age 1 hour, before the first colostrum feeding) and the $110 \mathrm{kD}$ polypeptide of the apical membrane of enterocyte enterocytes 3 days, showing the ability to selectively bind immunoglobulins. On the basis of the obtained data, the hypothesis of receptor-endocytotic mechanism of colostrum immunity formation in cattle was proposed (Tsvilikhovskyi, 1998). However, data on the structural proteins of the plasmolemma of the absorptive enterocytes of the cattle fetus in the early fetal period are absent. The purpose of the study is to investigate the ratio of structural proteins of plasmolemma of the jejunum absorbing enterocytes of the cattle fetus in the early fetal period.

\section{Materials and methods}

The research material was selected from 80 cattle, from 2 to 4 months old, obtained from clinically healthy cows, during forced slaughter in a meat processing establishment. The slaughter of animals was carried out in accordance with the requirements of the "European Convention for the Protection of Vertebrate Animals Used for Experimental and Scientific Purposes" (Strasbourg, 1985) and the decisions of the First National Congress on Bioethics (Kyiv, 2001). After euthanasia of the fetus, the abdominal section was dissected and the jejunum was isolated. An intestinal area was selected in the early fetal period (2, 3, 4 months) with an average length of $0.8 \mathrm{~m}$, which was cut lengthwise and divided into small segments by $1.5-3 \mathrm{~cm}$ and washed thoroughly (45 times) with cold $\left(4-6{ }^{\circ} \mathrm{C}\right)$ medium of the following composition: $120 \mathrm{mM} \mathrm{NaCl}$ and $1 \mathrm{mM}$ HEPES, the $\mathrm{pH}$ was 7.4 with a dry Trice. The method of cutting the intestine from the fetus of 2-4 months of age was used instead of rotation due to its small diameter. The basis for the selection of intestinal cells was the chemical (citrate/EDTO) method, on the basis of which an author's modification of the method was developed (Masiuk et al., 2008) production of isolated enterocytes of the jejunum intestine of cattle. To obtain apical membranes and basolateral membranes from the suspension of isolated enterocytes of the cattle fetus, we used the basic method of differential centrifugation (Tsvilikhovskyi, 1998) in our modification (Masiuk et al., 2008). The efficiency of obtaining fractions of the plasmolemma was carried out by the output of the membrane material by the amount of protein. Studies on the content and composition of the structural proteins of plasmolemic enterocytes were performed by polyacrylamide gel electrophoresis of $1 \mathrm{~mm}$ thickness (Laemmli, 1970). Acrylamide gradient $\mathrm{T}=7-18 \%$ was formed in the protein separation gel.

The results were analyzed using parametric and nonparametric statistical criteria for small samplings: Student's t-test. Changes in indicators were considered significant at $\mathrm{P}<0.05-0.001$, after testing the hypotheses about the normality of distribution and the difference between the general dispersions.

\section{Results and discussion}

The analysis of the obtained results shows that in the early fetal period (from two to four months of age of the fetus), 27 and 25 protein fractions were detected in the apical and basolateral membranes of the plasmolemma enterocytes of jejunum intestinum, respectively. It should be noted that most of the detected protein fractions of the apical membrane of the jejunum enterocytes of two-month-old cattle fetus were of low and medium molecular weight, in particular, proteins with a molecular weight of $9.6-14.2 \mathrm{kDa}$ were $9.06 \pm 0.08 \% ; 15.5 \mathrm{kDa}-5.91 \pm 0.05 \% ; 17 \mathrm{kDa}-2.47 \pm$ $0.03 \% ; 21 \mathrm{kDa}-5.81 \pm 0.04 \% ; 22.5 \mathrm{kDa}-6.10 \pm 0.05 \%$; $26 \mathrm{kDa}-5.15 \pm 0.02 \% ; 29 \mathrm{kDa}-2.78 \pm 0.03 \% ; 31 \mathrm{kDa}-$ $3.28 \pm 0.02 \%$; $33 \mathrm{kDa}-4.15 \pm 0.02 \%$; $35 \mathrm{kDa}-6.02 \pm$ $0.02 \% ; 37 \mathrm{kDa}-3.33 \pm 0.01 \% ; 39 \mathrm{kDa}-6.04 \pm 0.02 \%$. Proteins with higher molecular weight were found significantly smaller: $43 \mathrm{kDa}-3.33 \pm 0.02 \% ; 46 \mathrm{kDa}-3.99 \pm$ $0.02 \% ; 52 \mathrm{kDa}-6.16 \pm 0.03 \% ; 57 \mathrm{kDa}-4.23 \pm 0.02 \%$; 
$63 \mathrm{kDa}-4.19 \pm 0.02 \% ; 72 \mathrm{kDa}-3.02 \pm 0.01 \% ; 75 \mathrm{kDa}-$ $2.77 \pm 0.01 \% ; 87 \mathrm{kDa}-3.32 \pm 0.02 \%$. It should be noted that protein fractions with molecular weights of $100 \mathrm{kDa}$ and more were found only: $100 \mathrm{kDa}-1.15 \pm 0.01 \%$; $120 \mathrm{kDa}-2.07 \pm 0.01 \% ; 155 \mathrm{kDa}-2.11 \pm 0.02 \% ; 170$
$185 \mathrm{kDa}-1.45 \pm 0.01 \% ; 205 \mathrm{kDa}-2.11 \pm 0.01 \%$. There were no high molecular weight proteins in the apical membrane of the jejunum enterocytes of two-month-old cattle fetus with a molecular weight greater than $205 \mathrm{kDa}$ (Fig. 1).

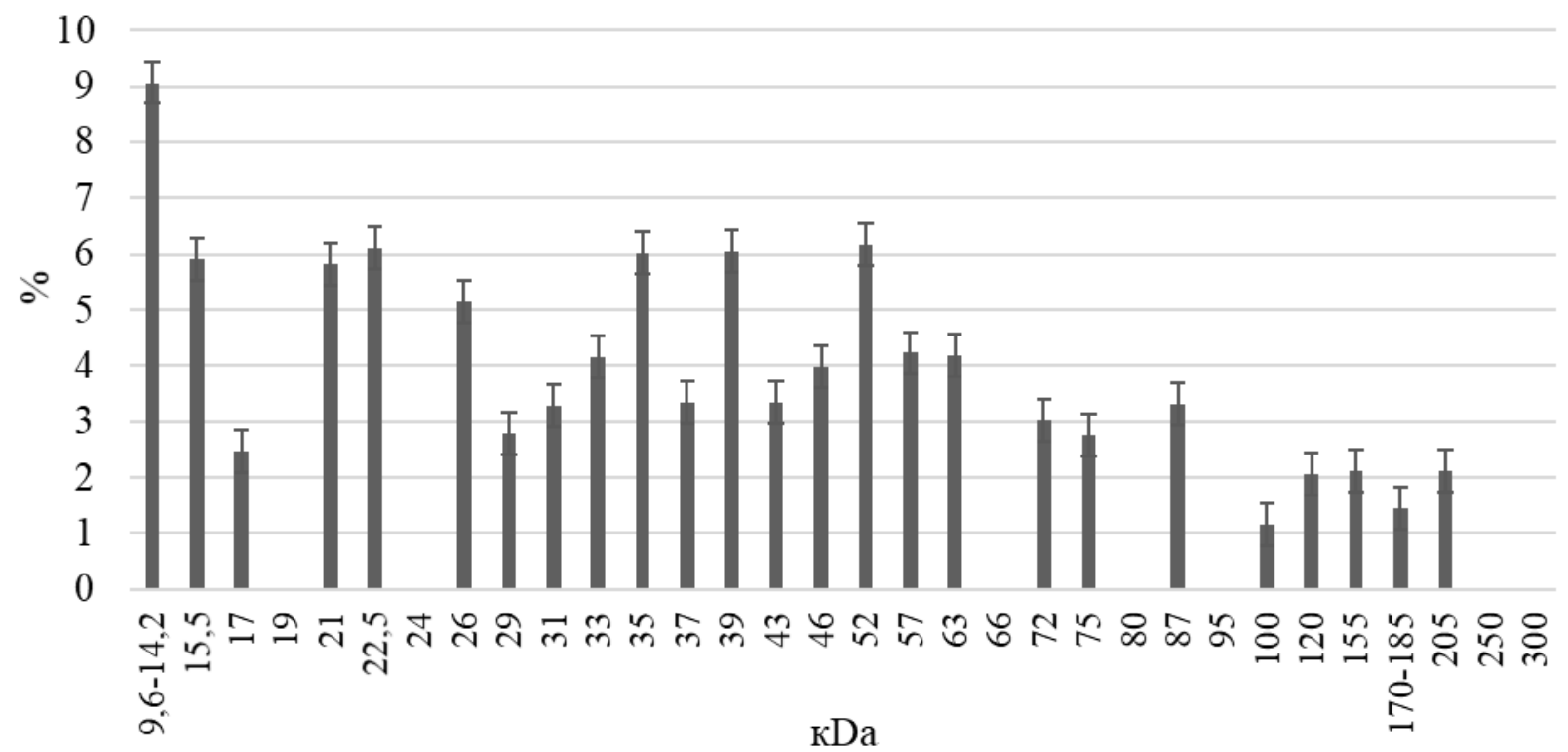

Fig. 1. Structural proteins of the apical membrane of the jejunum enterocytes of two-month-old cattle fetus $(M \pm m ; \% ; n=6)$

The composition of the low molecular weight polypeptides of the apical membrane of the jejunum enterocytes of the cattle from two to three months of age does not change significantly (Fig. 2). One should only note the increase in the percentage of proteins with a molecular weight of $29 \mathrm{kDa}(1.21$ times; $\mathrm{P} \leq 0.001)$ and a decrease in the percentage of proteins with a molecular weight of $21 \mathrm{kDa}$, $26 \mathrm{kDa}$ and $43 \mathrm{kDa}$ (respectively 1.27 times; $\mathrm{P} \leq 0.001,1.15$ times; $\mathrm{P} \leq 0.01$ and 1.11 times; $\mathrm{P} \leq 0.05$ ). At the same time, not only are the ratios of high molecular weight proteins of the apical membranes of enterocytes up to three months of age are chanded, but new fractions are also emerging. Thus, in apical membranes of small intestine enterocytes of three- month-old calf embryos, proteins with molecular weights of $250 \mathrm{kDa}$ and $300 \mathrm{kDa}(0.45 \pm 0.01 \%$ and $0.88 \pm 0.01 \%$, respectively) appeared, which were not present in the membranes of enterocytes fetus of two months of age. In addition, the content of protein fractions with a molecular mass of $100 \mathrm{kDa}, 120 \mathrm{kDa}$, and $155 \mathrm{kDa}$ from two to three months of age of the fetus increases respectively 1.43 times $(\mathrm{P} \leq 0.001), 1.18$ times $(\mathrm{P} \leq 0.01)$ and 1,61 times ( $\mathrm{P} \leq 0.001)$, however, the concentration of proteins with a molecular weight of $170-185 \mathrm{kDa}$ decreased by 1.20 times ( $\mathrm{P} \leq 0.001)$, and with a mass of $205 \mathrm{kDa}$ by 1.29 times $(\mathrm{P} \leq 0.001)$ during the indicated period of studies.

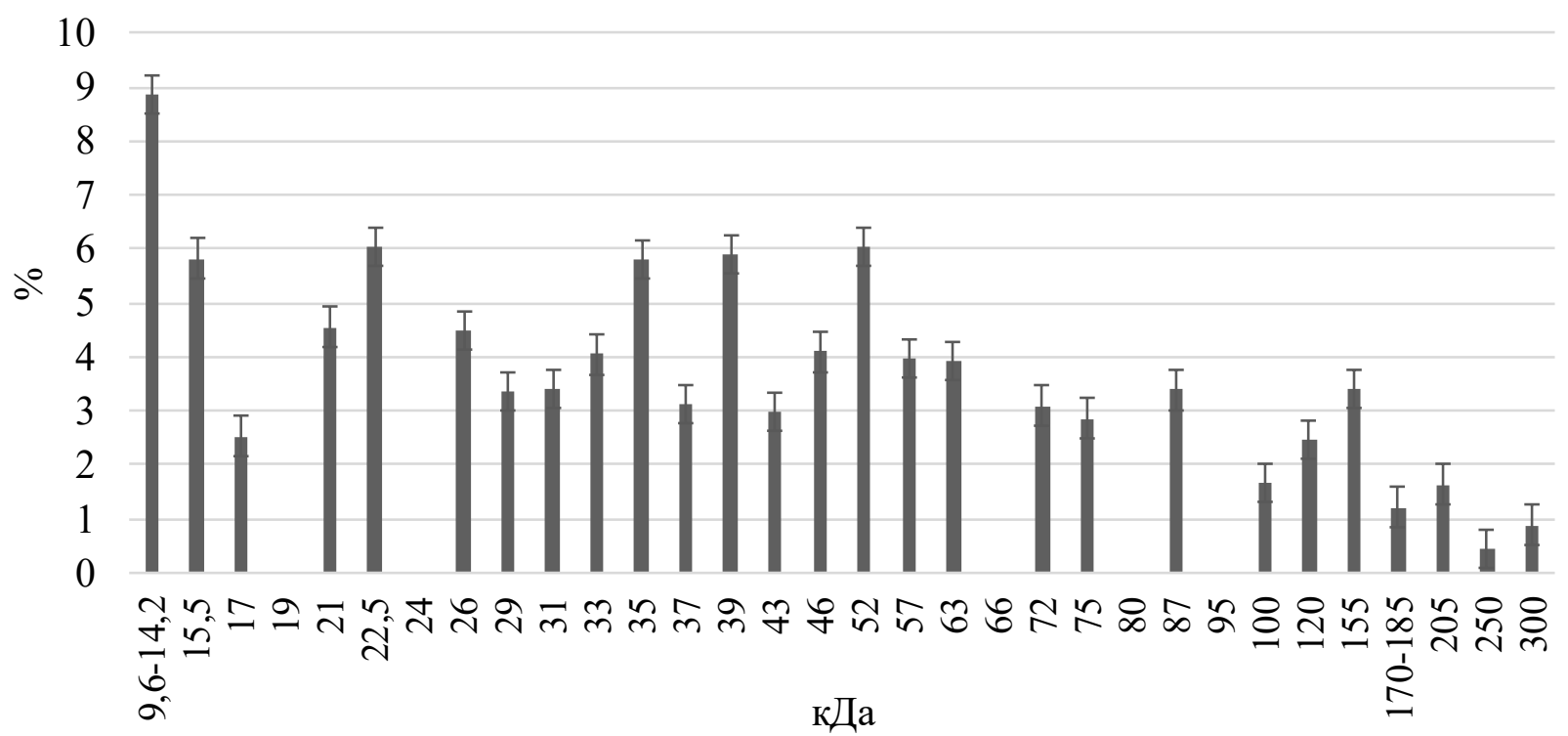

Fig. 2. Structural proteins of the apical membrane of the hollow enterocytes of three-month-old cattle fetus $(M \pm m ; \% ; n=6)$ 
From three to four months of age of cow fetus (Fig. 3), the relative content of low molecular weight polypeptides with a molecular weight of 9.6-14.2 kDa in the apical membrane of the jejunum enterocytes significantly decreased (1.34 times; $\mathrm{P} \leq 0.001)$. While the content of proteins with a molecular weight of $17 \mathrm{kDa}$ is increased 1.62 times $(\mathrm{P} \leq 0.001)$.

We also note a significant decrease in the percentage of proteins with a molecular weight of $22.5 \mathrm{kDa}$ (1.09 times; $\mathrm{P} \leq 0.05), 75 \mathrm{kDa}$ (1.18 times; $\mathrm{P} \leq 0.01), 120 \mathrm{kDa}(1.14$ times; $\mathrm{P} \leq 0.01)$ and $300 \mathrm{kDa}(1.16$ times; $\mathrm{P} \leq 0.01)$. It is evident that the decrease in the proportion of these proteins in the apical membrane of fetal enterocytes is due to the increase in the percentage of polypeptides with a molecular weight of $37 \mathrm{kDa}$ (1.22 times; $\mathrm{P} \leq 0.001), 87 \mathrm{kDa}(1.18$ times; $\mathrm{P} \leq 0.01)$ and $100 \mathrm{kDa}(1.13$ times; $\mathrm{P} \leq 0.05)$.

In the basolateral membranes of enterocytes of twomonth old cattle fetus, 23 protein fractions with a molecular weight from 9.6 to $120 \mathrm{kDa}$ were detected (Fig. 4). It is interesting to note the absence of polypeptide fractions with molecular weights of $22.5 \mathrm{kDa}, 37 \mathrm{kDa}, 155 \mathrm{kDa}$ and 170 $185 \mathrm{kDa}$, which are present in the apical membranes of these enterocytes. Instead, proteins with molecular weights of $19 \mathrm{kDa}, 24 \mathrm{kDa}$, and $66 \mathrm{kDa}$ are available on the basolateral membranes.

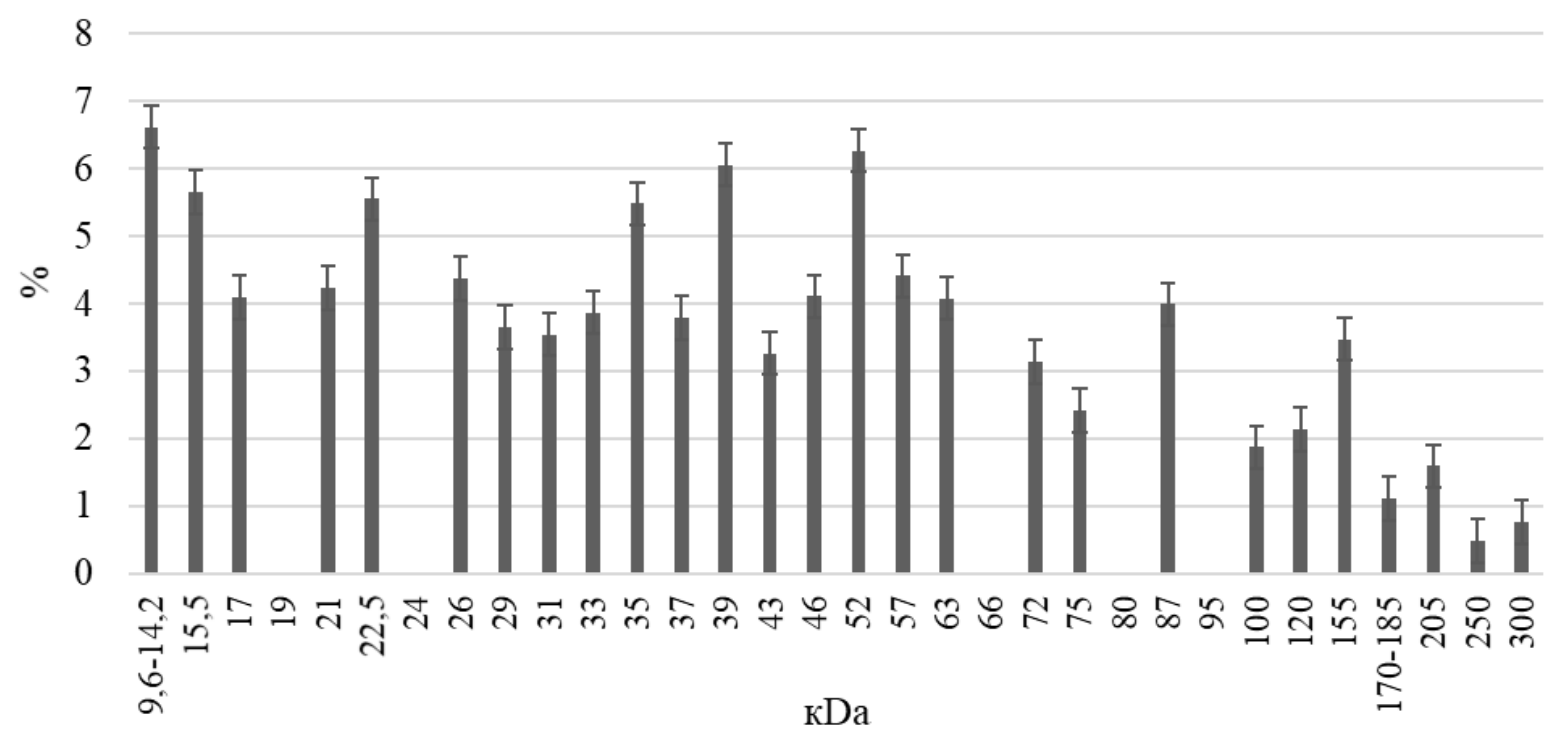

Fig. 3. Structural proteins of the apical membrane of the jejunum enterocytes of four-month-old cattle fetus

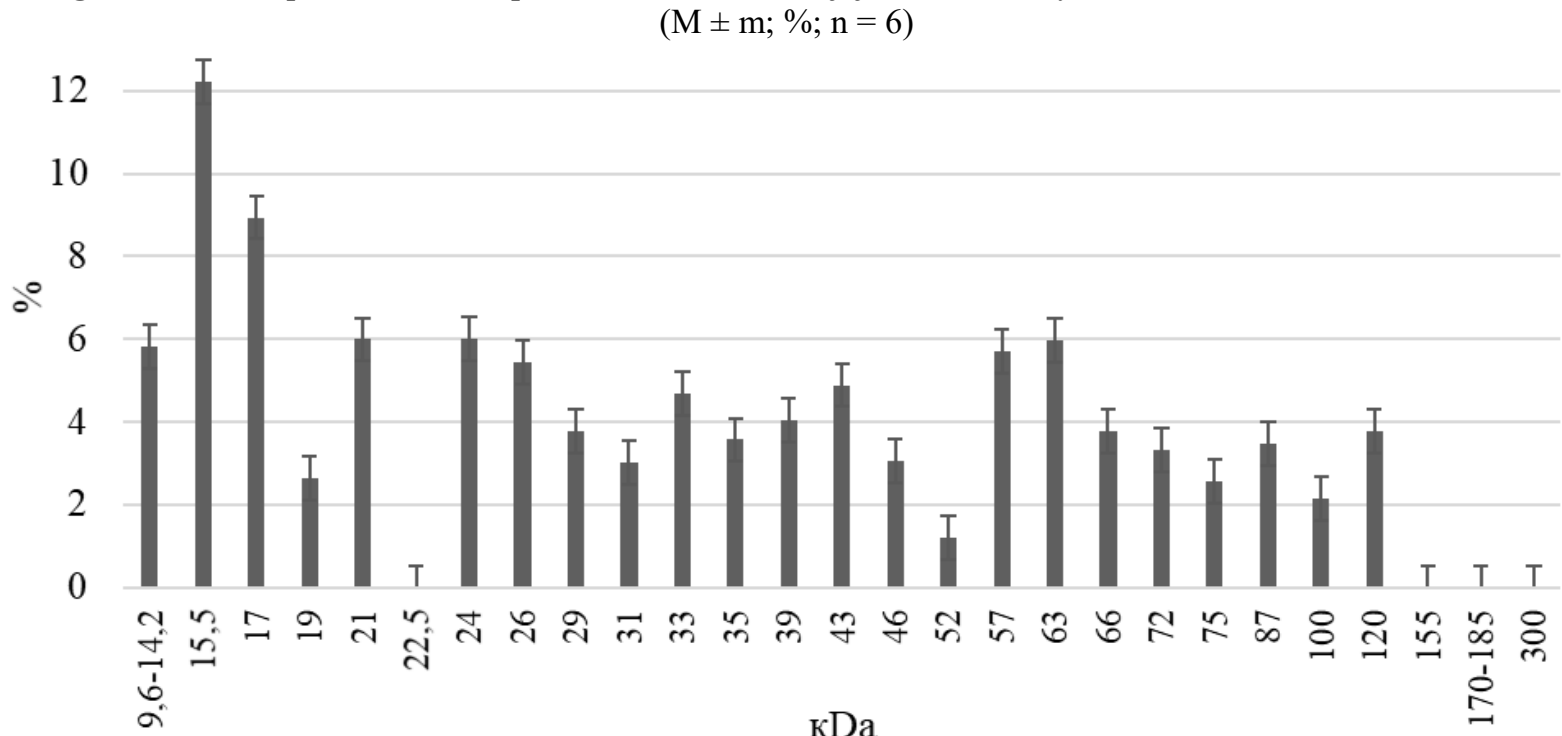

Fig. 4. Structural proteins of the basolateral membrane of the jejunum enterocytes of the two-month old cattle fetus $(\mathrm{M} \pm \mathrm{m} ; \% ; \mathrm{n}=6)$.

Most of the detected protein fractions were of low and medium molecular weight $(9.6-39 \mathrm{kDa}-59.12 \%)$. Proteins with a molecular weight of 40 to $100 \mathrm{kDa}$ revealed only $36.1 \%$, and protein fractions with a molecular weight of $100 \mathrm{kDa}$ or more were found in the amount of only 5.91 . There were no high molecular weight proteins in the basolateral membrane of the jejunum enterocytes of two-month- old cattle fetus with a molecular weight greater than 120 $\mathrm{kDa}$ by electrophoresis, unlike the apical membrane.

The composition of basolateral membrane polypeptides of the jejunum enterocyte membranes of cattle fetus from two to three months of age undergoes some changes, but they concern only their quantitative composition, whereas their qualitative composition does not change significantly (Fig. 5). 


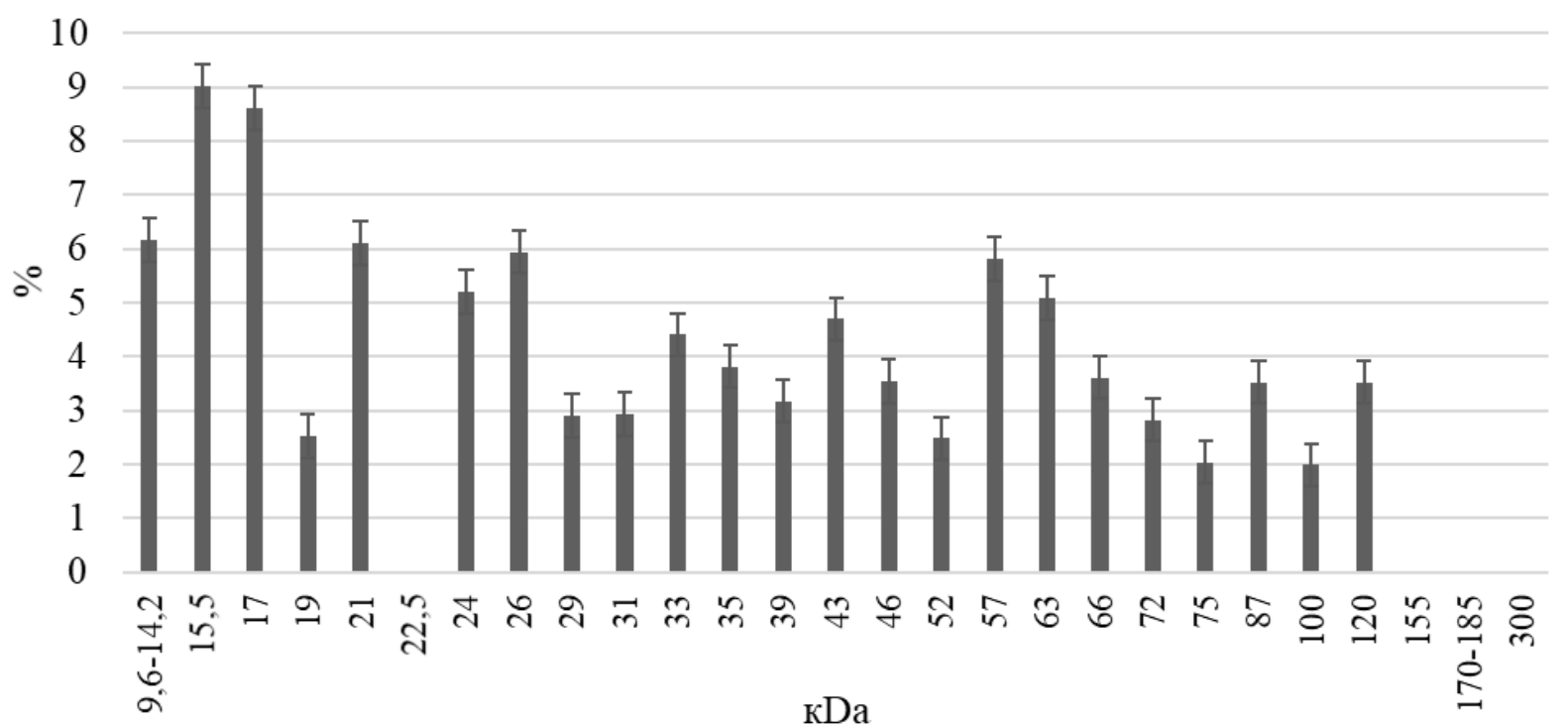

Fig. 5. Structural proteins of the basolateral membrane of the jejunum enterocytes of the three-month-old cattle fetus $(\mathrm{M} \pm \mathrm{m} ; \% ; \mathrm{n}=6)$

It should be noted that the increase in the basolateral membrane of enterocytes up to three months of fetus age of the percentage of proteins with a molecular weight of $46 \mathrm{kDa}$ and $52 \mathrm{kDa}$ in 1.16 times $(\mathrm{P} \leq 0.001)$ and 2.08 times $(\mathrm{P} \leq 0.001)$, respectively, compared to these indicators in two months. Moreover, the content of proteins with a molecular weight of $15.5 \mathrm{kDa}$ in 1.35 times $(\mathrm{P} \leq 0.001), 24 \mathrm{kDa}$ -1.15 times $(\mathrm{P} \leq 0.001), 29 \mathrm{kDa}-1.30$ times $(\mathrm{P} \leq 0.001)$, $39 \mathrm{kDa}-1.27$ times $(\mathrm{P} \leq 0.001), 63 \mathrm{kDa}-1.17$ times
$(\mathrm{P} \leq 0.01), 72 \mathrm{kDa}-1.18$ times $(\mathrm{P} \leq 0.01)$ and $75 \mathrm{kDa}-$ 1.25 times $(\mathrm{P} \leq 0.001)$ are decrease.

In the future, not only the ratio of high-molecular proteins of basolateral membranes of enterocytes changes from three to four months of age, but also new polypeptide fractions (Fig. 6). Thus, proteins with a molecular weight of $22.5 \mathrm{kDa}-4.55 \pm 0.05 \%$ and $155 \mathrm{kDa}-0.43 \pm 0.02 \%$ appear in the basolateral membranes of small intestine enterocytes of four-month-old calf embryos.

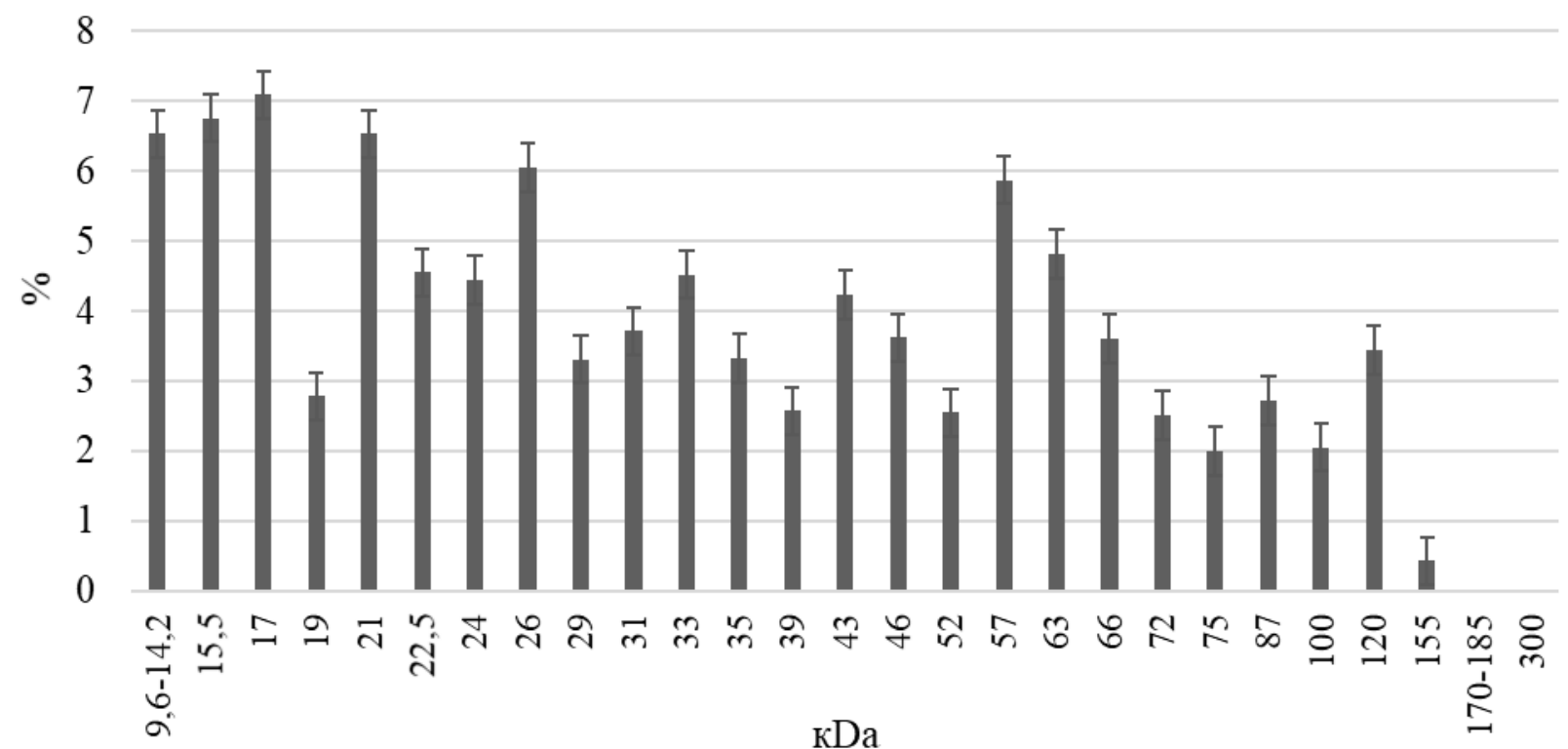

Fig. 6. Structural proteins of the basolateral membrane of the jejunum enterocytes of the four-month old cattle fetus $(\mathrm{M} \pm \mathrm{m} ; \% ; \mathrm{n}=6)$

It is necessary to note, among other things, a significant increase in the basolateral membranes of enterocytes from three to four months of age of the fetus of protein fractions with molecular weights of $19 \mathrm{kDa}, 29 \mathrm{kDa}$ and $31 \mathrm{kDa}$, respectively, in 1.10 times $(\mathrm{P} \leq 0.05), 1.14$ times $(\mathrm{P} \leq 0.01)$ and 1.27 times $(\mathrm{P} \leq 0.001)$. At the same time, during this research period, the concentration of proteins with a molecular weight of $15.5 \mathrm{kDa}$ in 1.33 times $(\mathrm{P} \leq 0.001), 17 \mathrm{kDa}-$ 1.21 times $(\mathrm{P} \leq 0.001), 24 \mathrm{kDa}-1.17$ times $(\mathrm{P} \leq 0.01)$,
$35 \mathrm{kDa}-1.15$ times $(\mathrm{P} \leq 0.01), 39 \mathrm{kDa}-1.24$ times $(\mathrm{P} \leq$ $0.001), 43 \mathrm{kDa}-1.11$ times $(\mathrm{P} \leq 0.05), 72 \mathrm{kDa}-1.13$ times $(\mathrm{P} \leq 0.05), 87 \mathrm{kDa}-1.30$ times $(\mathrm{P} \leq 0.001)$.

Analysis of the results of studies of basolateral membrane proteins of cattle fetus enterocytes in the early fetal period showed dynamic changes in their fractional composition. In the basolateral membranes of enterocytes, there is a slight decrease in the content of low molecular weight protein fractions, and four-month-old calf embryos show high 
molecular weight fractions of polypeptides with a molecular weight of $22.5 \mathrm{kDa}$ and $155 \mathrm{kDa}$, which are absent in basolateral membranes two- and three-month-old fetus.

Analysis of the results of electrophoresis of apical membranes proteins of fetus enterocytes in the early fetal period indicates a decrease in the content of low molecular weight protein fractions and an increase - high molecular weight. In addition, if high molecular weight fractions of $250 \mathrm{kDa}$ and $300 \mathrm{kDa}$ polypeptides appear in the calf embryos from the age of three months, which were absent in the apical membranes of the two-month old fetus enterocytes.

Protein distribution at the apical or basolateral membrane domain supports several mechanisms. First, in order to prevent free diffusion of proteins from one region to another, and paracellular diffusion of ions and solutes, there is a molecular fence at the boundary between the apical and basalateral membrane domains (apical binding complex AJC) (Shin \& Margolis, 2006). Second, several classes of membrane proteins bind to the complex of cytoplasmic scaffolds of ankyrin-spectrin on the basolateral membrane, including ion transporters and channels (Bennett \& Healy, 2008). These interactions are important in regulating the transport of membrane protein and its retention in different membrane domains.

The dynamics of the concentration of individual protein fractions at the apical and basolateral membranes of enterocytes significantly changes during the early study period, which indicates the intensive mechanisms of maturation and formation of polar cells in the corresponding stages of the fetal period. As noted earlier, the content of polypeptides is not uniform at the individual poles of enterocytes, so the proteins with molecular weights of $19 \mathrm{kDa}, 24 \mathrm{kDa}$, and $66 \mathrm{kDa}$ are absent in the apical membrane at two months, whereas there are no proteins at the basolateral membrane with weight of 155.5 and $22.5 \mathrm{Da}$. $\mathrm{kDa}, 170-185 \mathrm{kDa}$ and $205 \mathrm{kDa}$. Although the rest of the fractions of polypeptides in different poles of cells are common, their content is significantly different. Thus, in the apical membrane of enterocytes, a significantly higher number of proteins with a low molecular weight of $9.6-14.2 \mathrm{kDa}$ (1.56 times; $\mathrm{P} \leq 0.001$ ), whereas in the basolateral membrane a significantly higher concentration of proteins with a molecular weight of $15.5 \mathrm{kDa}(2.06$ times; $\mathrm{P} \leq 0.001)$ and $17 \mathrm{kDa}$ (3.62 times; $\mathrm{P} \leq 0.001)$.

\section{Conclusions}

In the early fetal period, there are dynamic changes in the protein composition of the apical and basolateral membranes of enterocytes, characterized not only by changes in their ratio within different cell domains, but also by dynamic redistribution of the number of different fractions of polypeptides between the poles of these cells.

\section{References}

Aroeti, B., \& Orzech, E. (1998). Polarized trafficking of plasma membrane proteins: emerging roles for coats, SNAREs, GTPases and their link to the cytoskeleton. Biochim. Biophys. Acta, 1376(1), 57-90. doi: 10.1016/s0304-4157(98)00005-7.

Bennett, V., \& Healy, J. (2008). Organizing the fluid membrane bilayer: Diseases linked to spectrin and ankyrin. Trends $\mathrm{Mol}$ Med, 14(1), 28-36. doi: 10.1016/j.molmed.2007.11.005.

Buhai, A. O., \& Tsvilikhovskyi, M. I. (2010). Zhyrnokyslotnyi sklad bazolateralnykh membran absorbtsiinykh enterotsytiv porozhnoi kyshky kurchat-broileriv za dii likopenu. Naukovyi visnyk Lvivskoho natsionalnoho universytetu veterynarnoi medytsyny ta biotekhnolohii im. Gzhytskoho, 3(2), 14-24 (in Ukrainian).

Caplan, M. J. (1997). Membrane polarity in epithelial cells: protein sorting and establishment of polarized domains. Am. J. Physiol., 272, F425-429. doi: 10.1152/ajprenal.1997.272.4.F425.

Casanova, J. E., \& Mostov, K. E. (1990). Phosphorylation of the polymeric immunoglobulin receptor required for its efficient transcytosis. $\quad$ Science, 248(4956), 742-745. doi: 10.1126/science.2110383.

Cereijido, M., \& Shoshani, L. (2004). Cell adhesion, polarity, and epithelia in the dawn ofmetazoans. Physiol Rev, 84(4), 12291262. doi: 10.1152/physrev.00001.2004.

Delacour, D., \& Jacob, R. (2006). Apical protein transport. Cell. Mol. Life Sci, 63, 2491-2505. doi 10.1007/s00018-006-6210-8.

Folsch, H. (2008). Regulation of membrane trafficking in polarized epithelial cells. Curr Opin Cell Biol, 20(2), 208-213. doi: 10.1016/j.ceb.2008.01.003.

Gravotta, D., \& Rodriguez-Boulan, E. (2007). AP1B sorts basolateral proteins in recycling and biosynthetic routes of MDCK cells. Proc Natl Acad Sci, 104(5), 1564-1569. doi: 10.1073/pnas.0610700104.

Jaulin, F., \& Kreitzer, G. (2007). Polarization-dependent selective transport to the apical membrane by KIF5B in MDCK cells. Dev Cell, 13(4), 511-522. doi: 10.1016/j.devcel.2007.08.001

Lafont, F., \& Simons, K. (1994). Involvement of microtubule motors in basolateral and apical transport in kidney cells. Nature, 372(6508), 801-803. doi: 10.1038/372801a0.

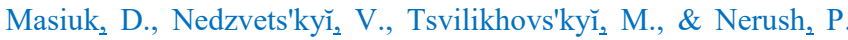
(2008). The changes of expression and Fc-gamma-receptor's polypeptide composition of fetal small intestine enterocytes in Bos primigenius taurus L. Physiological journal, 54(1), 27-34. https://www.ncbi.nlm.nih.gov/pubmed/18416181.

Mellman, I., \& Nelson, W. J. (2008). Coordinated protein sorting, targeting and distribution in polarized cells. Nat Rev Mol Cell Biol, 9(11), 833-845. doi: 10.1038/nrm2525.

Muth, T. R., \& Caplan, M. J. (2003). Transport protein trafficking in polarized cells. Annu. Rev. Cell Dev. Biol, 19, 333-366. doi: 10.1146/annurev.cellbio.19.110701.161425.

Nejsum, L. N., \& Nelson, W. J. (2007). A molecular mechanism directly linking E-cadherin adhesion to initiation of epithelial cell surface polarity. $J$ Cell Biol, 178(2), 323-335. doi: $10.1083 \% 2$ Fjcb. 200705094 .

Nelson, W. (2009). Remodeling Epithelial Cell Organization: Transitions Between Front Rear and Apical-Basal Polarity. Cold Spring Harb Perspect Biol. doi: $10.1101 /$ cshperspect.a000513.

Rodriguez-Boulan, E., \& Musch, A. (2005). Organization of vesicular trafficking in epithelia. Nat. Rev. Mol. Cell Biol, 6(3), 233-247. doi: 10.1038/nrm1593.

Rodriguez-Boulan, E., \& Powell, S. K. (1992). Polarity of epithelial and neuronal cells. Annu. Rev. Cell Biol, 8, 395-427. doi: 10.1146/annurev.cb.08.110192.002143.

Shin, K., \& Margolis, B. (2006). Tight junctions and cell polarity. Annu Rev Cell Dev Biol, 22, 207-235. doi: 10.1146/annurev.cellbio.22.010305.104219.

Simons, K., \& van Meer, G. (1988). Lipid sorting in epithelial cells. Biochemistry, 27(17), 6197-6202. doi: 10.1021/bi00417a001.

St Johnston, D., \& Sanson, B. (2011). Epithelial polarity and morphogenesis. Curr Opin Cell Biol, 23(5), 540-546. doi: 10.1016/j.ceb.2011.07.005.

Tilney, L. G., \& Mooseker, M. S. (1973). The polymerization of actin: its role in the generation of the acrosomal process of certain echinoderm sperm. J. Cell Biol, 59(1), 109-126. doi: $10.1083 \% 2 F j c b .59 .1 .109$.

Tsvilikhovskyi, M. I. (1998). Bilky plazmatychnoi membrany epiteliiu tonkoho kyshechnyka velykoi rohatoi khudoby: dys... d-ra biol. nauk: 03.00.04. Natsionalnyi ahrarnyi un-t. K. (in Ukrainian). 
Tsvilikhovskyi, M. I., \& Yakymchuk, O. M. (2014). Limitni faktory i patolohiia tvaryn antenatalnoho ta postnatalnoho rozvytku. Visn. Poltav. derzh. ahrar. akad., 3, 92-94 (in Ukrainian).
Yeaman, C., \& Nelson, W. J. (1999). New perspectives on mechanisms involved in generating epithelial cell polarity. Physiol. Rev, 79(1), 73-98. doi: 10.1152/physrev.1999.79.1.73. 